\title{
WIP: Emergence of Shared Leadership Dynamics during Engineering Stu- dent Design Projects
}

Dr. Malini Natarajarathinam, Texas A\&M University

Dr. Malini Natarajarathinam joined the faculty of Industrial Distribution Program at Texas A\&M University in 2007. Natarajarathinam received her Ph.D. in Supply Chain Management from The University of Alabama. She received her Bachelor of Engineering (Major: Industrial and Systems Engineering) from Anna University [Tamilnadu, India], her MS in Industrial Engineering from Auburn University, her MA in Management Science and MS in Applied Statistics from The University of Alabama. She has experience working with many industries such as automotive, chemical distribution etc. on transportation and operations management projects. She works extensively with food banks and food pantries on supply chain management and logistics focused initiatives. Her graduate and undergraduate students are integral part of her service-learning based logistics classes.

She teaches courses in strategic relationships among industrial distributors and distribution logistics. Her recent research focuses on engineering education and learning sciences with a focus on how to engage students better to prepare their minds for the future. Her other research interests include empirical studies to assess impact of good supply chain practices such as coordinated decision making in stochastic supply chains, handling supply chains during times of crisis and optimizing global supply chains on the financial health of a company. She has published her research in Journal of Business Logistics, International Journal of Physical Distribution and Logistics Management and peer-reviewed proceedings of the American Society for Engineering Education.

\section{Lei Xie, Texas A\&M University}

Lei Xie is a doctoral student at Texas A\&M University. He is currently majoring in Human Resource Development in the Department of Educational Administration \& Human Resource Development. His research interests include conflict management, organizational learning/change, knowledge management, learning organization, and International HRD. As a second year international graduate student from the People's Republic of China, he has been actively engaged in academic research. He is working on several book chapters and an independent research project on the subject of organization development/change and organizational learning. He earned a Master's degree in HRD from Texas A\&M University in 2013. He graduated from Henan University of Technology in China with a Bachelor's degree.

\section{Prof. Michael Beyerlein, Texas A\&M University}

Michael Beyerlein is a Professor in the Human Resource Development Graduate Program at Texas A\&M University. Formerly, he was professor and department head of Organizational Leadership \& Supervision at Purdue and prior to that Founding Director of the Center for Collaborative Organizations and Professor of Industrial/Organizational Psychology at the University of North Texas. His books, book chapters, and articles usually address the topics of teams and collaboration, creativity and innovation, knowledge management, and intangible capital. His research interests include: team creativity, emergence of virtual organizations, and innovation science. His most recent edited book is The handbook for high performance virtual teams with Jill Nemiro and others.

\section{Mr. Rodney Boehm, Texas A\&M University}

Rodney Boehm is the Director of Engineering Entrepreneurship and an Associate Professor of Practice in the Texas A\&M University College of Engineering. He has broad industry experiences, including over 35 years in all aspects of the telecommunications industry (sales, marketing, manufacturing, business development, and technical design), the creation of a telecommunications standard (SONET - Synchronous Optical Network) for the fiber optics industry that is still in use internationally over 30 years later, a wide variety of business experiences in international companies, and startup experiences. This has helped him lead a very successful industry career. 


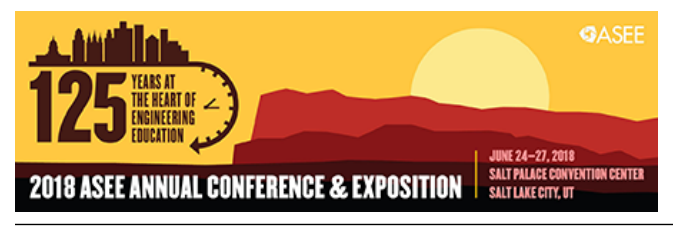

Paper ID \#23361

Currently he is using his technical business experiences to develop and run innovation and entrepreneurial programs for the Engineering Innovation Center, a 20,000 sq ft rapid prototyping facility. These include Aggies Invent, TAMU iSITE, Inventeer, and Pop Up Classes. In addition, he mentors multiple entrepreneurial teams.

Formerly he was a Senior Vice President of Fujitsu Network Communications, headquartered in Richardson, Texas. With over 30 years of experience in telecommunications, Rodney was responsible for developing partnerships with leading network technology providers and driving marketing efforts for optical, access and data products developed by Fujitsu. Rodney was Chairman of the T1X1 Technical Sub-Committee (the organization responsible for SONET standardization) from 1990 through 1994 . He has been active in SONET's National and International Standardization since 1985. In addition, Rodney has published numerous papers and presentations on SONET.

Rodney began his career with Fujitsu Network Communications in 1989 as the Director of Strategic Planning. He also held the positions of Director of Transport Product Planning, Vice President of Business Management, Senior Vice President of Sales Management, Senior Vice President of Manufacturing, and Senior Vice President of Business Development. Before joining Fujitsu, Rodney worked for Bell Laboratories, Bellcore (now Telcordia), and Rockwell International. He earned both his bachelor's and master's degrees in electrical engineering at Texas A\&M University.

\section{Dr. Jill Zarestky, Colorado State University}

Jill Zarestky, Ph.D., is an Assistant Professor of Adult Education and Training in the School of Education at Colorado State University. 


\section{Engagement in Practice: Engaging Undergraduate Students in a Multidisciplinary Service-Learning Environment}

Background and motivation

In today's integrated society, professionals and students alike rarely work solely with members of their own discipline and must learn to work collaboratively with others to solve problems. Increasingly, evidence supports the claim that millennials, in particular, are more likely to be engaged in problem solving if they feel that they can make a difference through the work that they are doing. Universities should support students' aspirations to contribute to society through coursework that helps integrate multidisciplinary classrooms and serve the surrounding communities. Because of the logistical demands that accompany these types of projects, servicelearning courses can be difficult to establish.

During the Spring semester of 2017, we created a distance-based service-learning project that integrated students enrolled in three different disciplines: industrial distribution (ID), technology management (TCMG), and sociology (SOCI). The goal of this project was to address food access and distribution disparities. Students from these three disciplines met once a week as a united class and once a week separately to learn skills pertinent to their respective courses. Students worked in small multidisciplinary groups paired with a food pantry in the region. To fully understand the challenges that the food pantries were experiencing, students met remotely with agents from the pantries using teleconferencing technology (e.g. Skype or WebEx). In this service-learning course, students were able to positively impact the community while simultaneously learning discipline-specific knowledge and developing their multidisciplinary communication, problem-solving, and research skills.

Course design and execution

According to Bringle and Hatcher [1], service-learning is defined as a "course-based, credit bearing educational experience in which students (a) participate in an organized service activity that meets identified community needs, and (b) reflect on the service activity in such a way as to gain further understanding of course content, a broader appreciation of the discipline, and an enhanced sense of personal values and civic responsibility" (p. 112)." Service-learning has been proven to benefit students in many ways. More specifically, service learning has been found to enhance students' collaboration skills [2], civic engagement, interpersonal skills [3], [4], and their ability to apply knowledge to problem-solving [5].

Our service-learning course was based on Chickering \& Ehrmann's seven principles for good practice in undergraduate education [6] as well as Kolb's Cycle of Experiential Learning [7]. Because we consider reflection to be a critical component of student learning [8] and servicelearning [9], we incorporated reflection assignments that gave students the chance to integrate their service experiences in this course with the disciplinary course materials. With these principles in mind, our service-learning course has two components: traditional face-to-face classroom learning and civic-engagement activities that took place outside of classroom that focus on 1) collaboration with peers; 2) active learning and exploration. 
There are many reasons to create a multidisciplinary environment. Previous literature shows that multidisciplinary team experiences simulate real world work environments, prepare (especially engineering) students for their future careers [10], enhance students' moral development [11], multicultural competence, and civic engagement [12]. For engineering majors, "an ability to function on multidisciplinary teams" was listed by The Accreditation Board of Engineering and Technology (ABET) as one of its desired educational outcomes [13]. A multidisciplinary service-learning approach has been used in computer-related academic programs as well to design for social change [14] and software development [15], as well as in the teaching of sociology [16], [17]. Furthermore, a multidisciplinary approach that paired engineering and nonengineering majors was successful in improving students' problem-solving and learning outcomes [10],[18],[19], [20], [21].

All integral and functional solutions consider people, processes, and technology. As a result, we attempted to incorporate these three aspects to ensure that our students' solutions would be welldesigned and impactful. With this in mind, we opened our multidisciplinary service-learning course to students enrolled in three different courses during the spring 2017 semester. These courses included IDIS 343 (Distribution Logistics, College of Engineering), TCMG 412 (Contemporary Issues in Technology Management, College of Education), and SOCI 217 (Introduction to Race and Ethnicity, College of Liberal Arts). There were 120 undergraduate students enrolled in this pilot semester. Students met in their discipline-specific courses every Tuesday and as a collective unit every Thursday. The course structure is shown in [Fig. 1] below.

Figure 1. Service learning course structure and team formation, spring 2017.

Tuesday classes Separate class meetings, learn discipline-specific knowledge

$$
\begin{gathered}
\text { Technical learning (50\%) } \\
\text { Exams, assignments }
\end{gathered}
$$
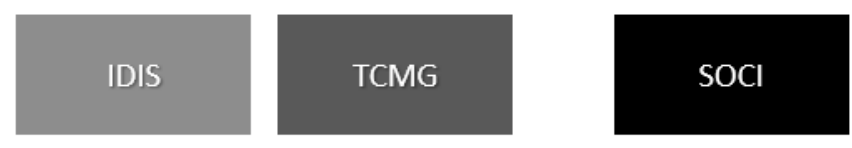

Thursday classes Combined class meetings, work on service-learning project

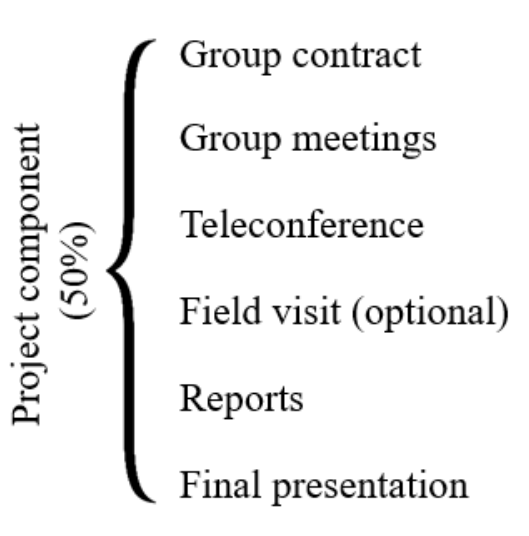

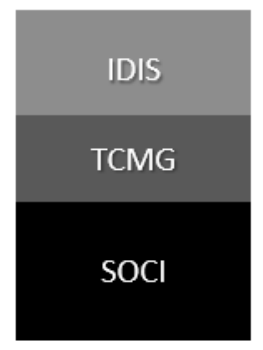

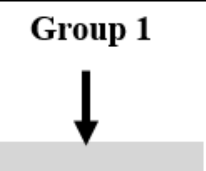

Pantry 1

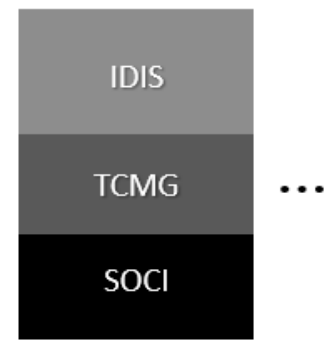

Group 2

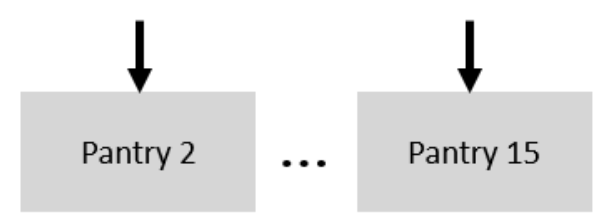

Note: depending on its size, a food pantry might have more than one student group assigned. 
This service-learning course combined classroom learning with community engagement activities to enhance students' learning through a hands-on experience involving peer collaboration, critical thinking and reflection. Students were divided into 28 small, multidisciplinary groups. Each group had at least one student from each course. These 28 teams worked with 15 food pantries/banks across Texas to help assess organizational needs and operational efficiency. Students were not given a specific problem to solve in advance. Rather, they were instructed to communicate with their partner agencies remotely (e.g. by using Skype or WebEx conference software) to find out what types of challenges the agency was experiencing. Students were prompted to conduct a needs assessment and create a feasible solution for challenges that they identified by integrating their discipline-specific knowledge. To facilitate the development of their needs assessment and project solutions, students completed several different group assignments over the course of the semester [Tab. 1].

Table 1. Project deliverables, service-learning pilot semester (spring 2017).

\begin{tabular}{|l|l|}
\hline Project Deliverables & Goal of Assignment \\
\hline Group Contracts & $\begin{array}{l}\text { Self-assessment focusing on individual strength and weakness, } \\
\text { learn to develop a pan to work productively and collaboratively. }\end{array}$ \\
\hline Writing Center Consultations & Improve digital communication and presentation skills. \\
\hline Report on State of Hunger in Texas & $\begin{array}{l}\text { Learn to conduct research and understand the big picture of } \\
\text { hunger status in Texas. }\end{array}$ \\
\hline Report on Community Partner Challenges & Report on discipline-specific challenges at the food pantries. \\
\hline $\begin{array}{l}\text { Report on Existing Food Assistance } \\
\text { Programs }\end{array}$ & $\begin{array}{l}\text { Learn the current policies to help envision a solution for food } \\
\text { pantry agencies. }\end{array}$ \\
\hline Statement of Work for Community Partner & Create integrative solutions across respective disciplines. \\
\hline Survey for Community Partner & $\begin{array}{l}\text { Learn how to design a survey and get feedback for their proposed } \\
\text { solutions. }\end{array}$ \\
\hline Needs Assessment for Community Partner & Identify organizational issues for designated food pantries. \\
\hline Final Presentation to Agencies & Foster creativity and presentation, storyboarding skills. \\
\hline
\end{tabular}

To explore students' learning outcomes, opinions about the course design, and experience working in teams, we conducted IRB-approved research throughout the pilot semester. At the beginning of the semester, students signed a consent form to indicate whether they wanted to participate in the research project. We collected both quantitative and qualitative data throughout the spring 2017 semester including face-to-face interviews, course evaluations, reflection assignments, a pre-survey, and a post-survey (see Tab. 2 below). These assessments combined open-ended, Likert scale, and multiple-choice style questions. All research instruments were IRB approved, and the responses of students who indicated that they did not want to participate were dropped before any data was analyzed. The quantitative data were analyzed in SPSS 20.0 (Statistical Package for the Social Sciences), and the qualitative data were transcribed, coded and analyzed in NVIVO 11. 
Table 2. Research assessment for service-learning class, spring 2017.

\begin{tabular}{|l|l|l|l|}
\hline Assessments & Format & Participants & Date sent \\
\hline Pre-test & Qualtrics survey & All students enrolled, 112 respondents & Jan. 26 2017 \\
\hline General Reflection & Qualtrics survey & All students enrolled, 30 respondents & Apr. 19 2017 \\
\hline $\begin{array}{l}\text { IDIS students Reflection } \\
\text { Assignment }\end{array}$ & eCampus assignment & IDIS students enrolled, 50 respondents & Apr. 23 2017 \\
\hline Reflection 2 & Qualtrics survey & $\begin{array}{l}\text { Random sample of all students enrolled, 18 } \\
\text { respondents }\end{array}$ & Apr. 26 2017 \\
\hline Final interview & Face-to-face & $\begin{array}{l}\text { Recruited from all students enrolled, 10 } \\
\text { respondents }\end{array}$ & April 26 2017 \\
\hline Post-test & Qualtrics survey & All students enrolled, 96 respondents & Apr.28 2017 \\
\hline
\end{tabular}

Impact on students' learning

Although the improvement of course grades was not our primary goal, we were curious to see how the service-learning component influenced students' learning outcomes. The IDIS 343 (Distribution Logistics) class had three sections, section 501, 502 and section 503, which were taught by the same professor. The three sections were intended to cover the same material and were assessed using several of the same instruments including seven homework assignments and two exams. However, only one of the three sections was involved in the service-learning project and utilized the accompanying deliverables listed in Table 1. To examine difference in students' learning outcomes between the three IDIS classes, we compared the grades of the students on shared assignments. We ran an independent t-test in SPSS to compare 128 ID students enrolled in the two regular (non-SL) sections (control group), and 60 ID students enrolled in the servicelearning (SL) section (experimental group). The average exam I grade was 164 points out of 200 possible points for SL students and 168 for non-SL students. The average exam II grade for SL students was 170 and 176 for non-SL students. Although SL students obtained slightly lower grades than non-SL students, the difference was not statistically significant (sig. values $>0.05$ for the t-test). We then compared ID students' homework grades using the averaged the grades of seven homework assignments. SL students had slightly higher average homework grades (15.02 out of 20 points) than non-SL students (14.99 out of 20 points), the difference was not statistically significant (sig. value > .05). Furthermore, when comparing the outcomes for service-learning students across majors, engineering students scored slightly higher final grades (886.04 out of 1,000 points) than non-engineering majors (885.99 out of 1,000 points) although the difference was not statistically significant (sig. value > .05).

Impact on student experience

Student interviews: We recruited a random sample of ten students with different academic majors for face-to-face interviews. The goal of these interviews was to understand students' course experiences and how these experiences influenced the development of their critical thinking, leadership, and problem solving skills. After analyzing the data, several themes emerged: (1) experiences with a multidisciplinary service-learning course design vs. traditional course design, (2) project ambiguity, and (3) students' perceived personal growth. 
Course Design: Compared to traditional courses, this service-learning course was different in several ways. To begin with, students thought that this project was very meaningful. As one student commented,

They [the food pantries] are so close by so it's something tangible, it's in our backyard, this is something that we can actually help and just our contacts being so positive and excited for us was very helpful.

Several of the students also felt that the multidisciplinary nature of the course made communication and coordination difficult. As one student said, "The group members didn't really mesh well together." However, they agreed that it also provided ample opportunity to learn in a real-world environment. As these two students remarked,

"The other two members brought in other ideas that wouldn't have been thought of..." "I understand the importance of group projects, it's awesome, it's a collaborative world and we are very social people. Learning to work in a group was great ... I think there were students who learned to work in group projects better so I think that can be applied to any career."

Project Ambiguity: Students also pointed out that the open-ended problem-solving process and flexible project structure was frustrating at times. They also expressed regrets about their inability to visit their partner pantries in person.

"It was a little harder being an open project, we ourselves had to come up with an idea, we as ourselves had to come up with how we are going to do it and everything else that encompassed it."

"Unique problems can come up and you never know what's going to happen and you have to be prepared for the situation, so that helped, but at the same time I felt like a job would be more structured."

"With the traditional course, everything is set like you have your stuff, and then this one it was kinda hard because it depended on other factors, like the agency getting back to you, and information, and trying to get all the data, it was a little bit harder, but they were really helpful and understanding about it so I think that helped a lot."

"I wished that [visit to food pantry] could have happened, because hearing about what a non-profit does is different from witnessing it and seeing exactly what you're doing."

Personal Growth: When asked if they felt the course had influenced their personal/professional growth, the answers were quite positive:

"[The group project] definitely improved [my leadership skills], because sometimes you just have to take charge and be willing to communicate your honest feelings like what needs to be done to get things done."

"Working with the other IDIS student, [my collaboration skill was] definitely [improved] a lot because normally I just do it by myself but working with someone else I had to get everything to flow and so that improved a lot."

Course evaluations

At the end of the semester, we collected engineering students' feedback regarding course content, instructors, and fairness of grading. The majority of the students considered the grading 
as fair, and the aspects they liked about this course included the meaningful project ideas, learning opportunity beyond classroom, enthusiastic and knowledgeable instructor, and the informative content of course materials. Below are some excerpts from students' course evaluations:

"[The instructor] cares about social issues and wants to increase students' awareness"; "I love being able to incorporate class concepts in the real world"; "She [the instructor] knows what she's talking about and can transfer knowledge well to us"; "She cares about her students understanding of the material."

The aspects of this course that they did not like included the disorganized structure, and perceived communication barriers. Below are some comments made by the IDIS students.

"Group essays are way to[o] confusing to organize and everyone has a different voice when they write."

"Not enough office hours."

"Answers to questions aren't always clear."

Consistent with the face-to-face interviews, students had mixed feelings regarding the group project. When ask for additional comments about the course and the instructor, some students answered:

"I enjoyed working with my group and I believed I actually learned 'real life' things";

"The Famine to Feast project was good but the deadline was not set well."

"I personally really enjoyed the famine to feast part of this course, but I know many students strongly disagree. I think they simply did not want to put more work than what they're used to."

Lessons learned from the pilot semester

The first-year pilot semester provided many insights with regard to course design. From the students' perspective, this multidisciplinary service-learning project had both positive and negative influences on their course experience and learning outcomes. For instance, letting students conduct open-ended needs assessments for the food pantries added difficulty to the service-learning project and slowed down project progress. Although student groups were intentionally designed to be multidisciplinary, it made collaboration and team management more challenging. We did not do very well engaging with the food pantry agencies, one student group, for example, indicated that their food bank agency was difficult to contact. In another case, the food pantry ended up working more efficiently with one of their students groups than the other. As a result, communication between one group and the agency was less efficient than with the other - which slowed down project development for the less favored group.

Conclusions and next steps

We expected the service-learning component to positively influence students' learning outcomes [1], [2]. However, one of the indicators of learning outcomes, course grades, did not differ for service-learning IDIS students and regular IDIS students. This could be simply because they learned the same disciplinary knowledge and were tested on the same technical content. It also reflected that although the service-learning project added a lot of extra workload, it did not 
negatively influence service-learning IDIS students' course grades, which proved that servicelearning project and technical learning were well balanced.

Students' interviews and course evaluations revealed that there is great potential for this servicelearning course. Though students felt this particular project (not the course) lacked structure, they still believed that working this type of impactful project motivated them to engage in the project. By collaborating with multidisciplinary teams, the students reported they gained awareness of social issues, as well as improved their critical thinking, problem solving, leadership, and communication skills, which are also indicators of good learning outcomes.

The results of this study were meaningful in two ways. First, the outcomes of the servicelearning project demonstrated the synergy of multidisciplinary knowledge in resolving existing social issues, i.e. students from different academic backgrounds helped local food pantries to serve more people at a lower cost through collaboration. Secondly, it helped us better identify the gap between what is offered by this course and students' actual needs. Based on the lessons learned from this pilot semester, we have made several changes to the course design. In our second semester, only students taking course credits from IDIS and SOCI were allowed to enroll. We also added new participation rules for food pantry agencies to improve communication and engagement between students and their partner agencies. Pantries that could not commit to attending at least four conference calls with their assigned student groups, for example, were disqualified from the program. To ensure students were more fully prepared for the course project, we also sought to clarify specific project objectives and deliverables for each student group and to emphasize the importance of group contracts and peer evaluations. To increase students' understanding of how food banks and food pantries work, we also added a mandatory field trip to Central Texas Food Bank (CTFB).

Excitingly, our strategic partner, CTFB is now allocating funds to reward food pantries based on the impact, feasibility, and creativity of student project proposals. Because of this addition, and the added stipulation that pantries identify a problem for students to work on ahead of time, we are expecting to see higher levels of student and agency motivation and engagement. With this monetary award at stake, we also anticipate an improvement in the quality of this year's project proposals. 
References

[1] R. G. Bringle and J. A. Hatcher, “A service-learning curriculum for faculty,” Michigan Journal of Community Service Learning, pp. 112-122, 1995.

[2] S. J. Peterson and M. J. Schaffer, "Service learning: A strategy to develop group collaboration and research skills," Journal of Nursing Education, vol. 38, no. 5, pp. 208-214, 1999.

[3] C. I. Celio, J. Durlak, and A. Dymnicki, "A meta-analysis of the impact of service-learning on students," Journal of Experiential Education, vol. 34, no. 2, pp. 164-181, 2011.

[4] M. J. Gray, E. H. Ondaatje, R. D. Fricker Jr, and S. A. Geschwind, “Assessing servicelearning: Results from as survey of 'learn and serve America, higher education'," Change, vol. 32, no. 2, pp. 30-39, 2000.

[5] J.R. Kendrick Jr, "Outcomes of service-learning in an introduction to sociology course," Michigan Journal of Community Service Learning, vol. 3, pp. 72-81, 1996.

[6] A. W. Chickering and Z. F. Gamson, "Seven principles for good practice in undergraduate education," AAHE bulletin, pp. 3-7, 1987.

[7] D. A. Kolb, Experiential Learning: Experience as the Source of Learning and Development. Englewood Cliffs, NJ: Prentice Hall, 1984.

[8] S. L. Ash, P. H. Clayton, and M. P. Atkinson, "Integrating reflection and assessment to capture and improve student learning," Michigan Journal of Community Service Learning, vol. 11, no. 2, pp. 49-60, 2005.

[9] D. E. Giles Jr and J. Eyler, "The theoretical roots of service-learning in John Dewey: Toward a theory of service-learning," Michigan Journal of Community Service Learning, vol. 1, no. 1, pp. 77-85, 1994.

[10] A.D. Christy and M. Lima, "Developing creativity and multidisciplinary approaches in teaching engineering problem-solving," International Journal of Engineering Education, vol. 23, no. 4, pp. 636, 2007.

[11] M.L. Bernacki and E. Jaeger, "Exploring the impact of service-learning on moral development and moral orientation," Michigan Journal of Community Service Learning, vol. 14, no. 2, 2008.

[12] A. Einfeld and D. Collins, "The relationships between service-learning, social justice, multicultural competence, and civic engagement," Journal of College Student Development, vol. 49, no. 2, pp. 95-109, 2008.

[13] Criteria for accrediting engineering programs 2017-2018. [Online]. Available: http://www.abet.org/accreditation/accreditation-criteria/criteria-for-accrediting-engineeringprograms-2017-2018/. [Accessed: Apr. 18, 2018].

[14] C. Cárdenas, "A multidisciplinary approach to teach the design of socially relevant computing systems for social change," The International Journal of Engineering Education, vol. 27, no. 1, pp.3-13, 2011.

[15] J. Chao and J. Brown, "Cross-departmental collaboration for the community: Technical communicators in a service-learning software engineering course," in Informing Science \& Information Technology, vol. 6, 2009.

[16] D. Rooks and C. Winkler, "Learning interdisciplinarity: Service learning and the promise of interdisciplinary teaching," Teaching Sociology, vol. 40, no. 1, pp. 2-20, 2012.

[17] M. Belliveau, "Interdisciplinary service-learning: Building student competencies through the cross-cultural parent groups project," Advances in Social Work, vol. 12, no. 1, pp. 79-93, 2011. 
[16] L.H. Jamieson, "Service learning in computer science and engineering," in Proceedings of the $33^{\text {rd }}$ SIGCSE Technical Symposium on Computer Science Education, Feb 27- Mar 03, 2002, vol. 34, no. 1, pp. 133-134.

[17] K. Wei, J. Siow, and D.L. Burley, "Implementing service-learning to the information systems and technology management program: A study of an undergraduate capstone course," Journal of Information Systems Education, vol. 18, no. 1, pp. 125, 2008.

[18] E.A. Martinez-Mier, A.E. Soto-Rojas, S.M. Stelzner, D.E. Lorant, M.E. Riner, and K.M. Yoder, "An international, multidisciplinary, service-learning program: An option in the dental school curriculum," Education for Health, vol. 24, no. 1, pp. 259, 2011.

[19] L. Wright and M. Lundy, "Blogging as a tool to promote reflection among dietetic and physical therapy students during a multidisciplinary international service-learning experience," Journal of Allied Health, vol. 41, no. 3, pp. 73E-78E, 2012. 